\title{
KARAKTERISTIK DAN PENGOBATAN PASIEN PNEUMONIA DI INSTALASI RAWAT INAP RSUD ABDUL WAHAB SJAHRANIE SAMARINDA
}

\author{
Meilita Efliana*, Jaka Fadraersada, Laode Rijai \\ Laboratorium Penelitian dan Pengembangan FARMAKA TROPIS Fakultas Farmasi \\ Universitas Mulawarman, Samarinda, Kalimantan Timur \\ *email:meimel.litaef@gmail.com
}

\begin{abstract}
ABSTRAK
Infeksi saluran napas, khususnya pada pneumonia merupakan infeksi yang penyebarannya sangat luas yakni melanda bayi, anak-anak, hingga dewasa. Kasus Pneumonia di Provinsi Kalimantan Timur pada tahun 2013 dengan jumlah perkiraan kasus sebesar 37.310 kasus meningkat dari tahun sebelumnya 2012 sebanyak 35.377 kasus. Penelitian ini dilakukan secara non eksperimental (survei) bersifat deskriptif dan pengumpulan data dilakukan secara retrospektif dengan menggunakan catatan rekam medik pasien. Teknik sampling yang digunakan adalah purposif sampling. Dari 97 sampel diperoleh persentase terbesar laki-laki 51 pasien sebesar $52,58 \%$. Persentase usia yang paling banyak ialah $0-5$ tahun sebesar $58 \%$. Pengobatan pada penggunan antibiotik golongan dan jenis obat yang paling banyak digunakan adalah golongan sefalosporin $47,30 \%$ yakni dengan jenis antibiotik seftriakson. Rute pemberian obat antibiotik yang paling banyak diberikan ialah secara intravena sebesar $88,76 \%$. Frekuensi pemberian obat antibiotik yang diberikan bervariasi tergantung pada spesien bakteri target. Terapi suportif yang banyak digunakan ialah golongan bronkodilator $33,11 \%$. Interaksi obat yang terjadi berupa interaksi farmakodinamik dan interaksi farmakokinetik.
\end{abstract}

Kata Kunci: Pneumonia, Retrospektif, RSUD. A. W. Sjahranie Samarinda

\section{ABSTRACT}

Respiratory infections, particularly pneumonia is totally widespread that is struck infants, children and adolescents. Pneumonia's case in Kalimantan Timur on 2013 which the amount estimated is about 37.310 issues that has been increased from the previous year 2012 with total 35.377 issues. The research is conducted with non-experimental descriptive (survey) and data collection is conducted by using retrospection and utilized patient's medical record. The sampling used is purposive sampling. From 97 samples, it has been acquired the largest percentage was 51 males (52.58\%). The percentage of age in the range 0-5 is $58 \%$. Treatment of the use of antibiotic classes and types of drugs most widely used class of cephalosporin is $47.30 \%$ which is the type of antibiotic ceftriaxone. Route of administration of antibiotic drugs most widely prescribed intravenously is at $88.76 \%$. The frequency of administration of antibiotics given varies depending on the target species of bacteria. Supportive therapy is the widely used class of bronchodilators $33.11 \%$. Interactions that occur is pharmacodynamic interaction and pharmacokinetic interaction.

Keywords: Pneumonia, Retrospective, RSUD Wahab Sjahranie Samarinda

\section{PENDAHULUAN}

Pneumonia merupakan infeksi di ujung bronkhioli dan alveoli yang dapat disebabkan oleh berbagai patogen seperti bakteri, jamur, virus dan parasit. Pneumonia dapat terjadi sepanjang tahun dan dapat melanda semua usia (Depkes RI, 2005). 
Tingginya prevalensi infeksi saluran pernapasan serta dampak yang ditimbulkannya membawa akibat pada tingginya konsumsi obat bebas (seperti anti influenza, obat batuk, multivitamin) dan antibiotika. Dalam kenyataan antibiotika banyak diresepkan untuk mengatasi infeksi ini. Salah satu penyebabnya adalah ekspektasi yang berlebihan para klinisi terhadap antibiotika terutama untuk mencegah infeksi sekunder yang disebabkan oleh bakteri, yang sebetulnya tidak bisa dicegah. Dampak dari semua ini adalah meningkatnya resistensi bakteri maupun peningkatan efek samping yang tidak diinginkan.

Pengetahuan dan pemahaman tentang infeksi ini menjadi penting di samping karena penyebarannya sangat luas yaitu melanda bayi, anak-anak dan dewasa, menyebabkan hilangnya hari kerja ataupun hari sekolah, bahkan berakibat kematian. Standar diagnosa dan terapi menjadi acuan dalam terapi penyakit pneumonia, yang diharapkan penggunaan antibiotik akan lebih selektif. Pemilihan dan penggunaan terapi yang tepat dan rasional akan menentukan keberhasilan terapi dan menghindari terjadinya resistensi bakteri. Selain itu tidak menutup kemungkinan penggunaan antibiotik dan obat-obat lain pada terapi pasien pneumonia dapat meningkatkan peluang terjadinya Drug Related Problems (DRPs), sehingga farmasi harus dapat mendeteksi, mengantisipasi, dan mencegah masalah-masalah yang terjadi atau akan terjadi dalam pengelolaan dan penggunaan antibiotika dan obat lainnya.

\section{TUJUAN}

Mengetahui karakteristik dan pengobatan pasien pneumonia di instalasi rawat inap Rumah Sakit Umum Abdul Wahab Sjahranie Samarinda yang meliputi karakteristik pasien dan pemilihan golongan dan jenis obat, frekuensi dan rute pemberian obat serta adanya potensi interaksi obat

\section{METODOLOGI PENELITIAN}

Penelitian ini dilakukan secara deskriptif dengan pengambilan data cara retrospektif. Metode yang digunakan adalah teknik purposif sampling. Penelusuran data rekam medik diperoleh dengan cara mengobservasi satu per satu kartu rekam medik. Berdasarkan dari penelusuran data rekam medik yang memenuhi kriteria inklusi sebanyak 97 pasien, yaitu pasien dengan diagnosa terakhir pneumonia serta mendapat terapi utama antibiotik. Dari data tersebut kemudian dianalisis dan didistribusikan dalam bentuk diagram maupun tabel berdasarkan karakteristik pasien yang meliputi jenis kelamin dan usia, dan pengobatan pasien pneumonia yang meliputi pemilihan jenis dan golongan obat, frekuensi pemberian, rute pemberian, dan potensi interaksi obat.

\section{HASIL DAN PEMBAHASAN}

\section{Karakteristik}

\section{a. Deskripsi Pasien Pneumonia Berdasarkan Jenis Kelamin}

Berdasarkan pada jenis kelamin pasien pneumonia yang dirawat di Instalasi Rawat Inap RSUD Abdul Wahab Sjahranie Samarinda tahun 2015 diderita oleh pasien laki-laki sebesar $53 \%$ dan perempuan $47 \%$. 


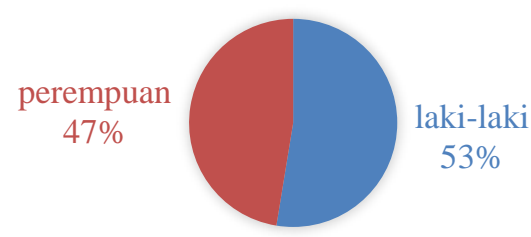

Gambar 1 Diagram Distribusi Jenis Kelamin Pasien Pneumonia di Instalasi Rawat Inap RSUD A. W. Sjahranie Samarinda Periode Tahun 2015

Diagram di atas menunjukkan dari total sampel 97 pasien pneumonia, angka kejadian pneumonia lebih tinggi diderita oleh laki-laki sebesar 53\%. Menurut Depkes RI (2004), lakilaki mempunyai faktor resiko 2 kali lebih tinggi dibanding perempuan. Laki-laki mempunyai faktor resiko lebih besar dibanding perempuan karena diameter saluran pernapasan laki-laki lebih kecil dibandingkan perempuan, selain itu terdapat perbedaan daya tahan tubuh antara laki-laki dan perempuan. Berdasarkan penelitian dari Profesor Katsuiku Hirokawa dari Jepang, menemukan bahwa hormone testoteron yang banyak pada laki-laki bisa mengurangi respon imun. Dengan demikian, laki-laki gampang terserang penyakit daripada perempuan. Mekanisme mengapa pneumonia lebih banyak diderita oleh laki-laki belum diketahui pasti (Hartati, 2011).

\section{b. Deskripsi Pasien Pneumonia Berdasarkan Usia}
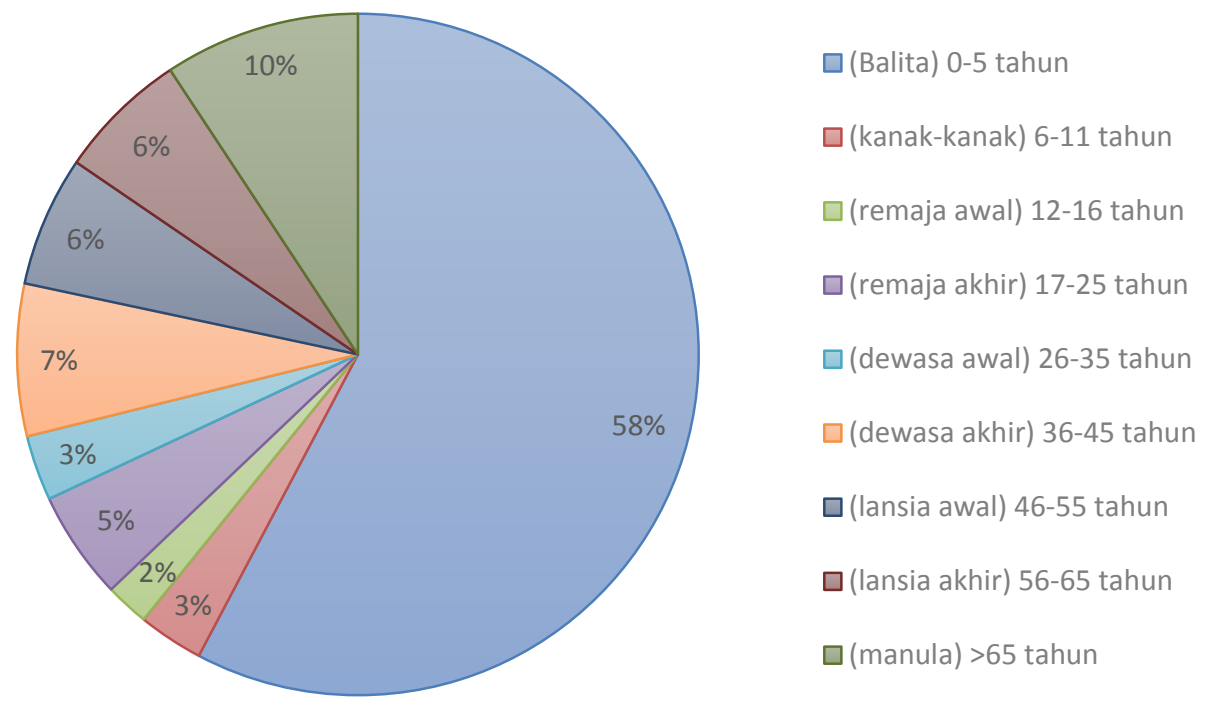

Gambar 2 Diagram Distribusi Usia Pasien Pneumonia di Instalasi Rawat Inap RSUD A. W. Sjahranie Samarinda Periode Tahun 2015 
Angka kejadian kasus pneumonia hampir terdapat pada tiap tingkatan usia, yakni pasien usia balita (0-5 tahun) sebesar 58\%, usia kanak-kanak (6-11 tahun) sebesar 3\%, usia remaja awal (12-16 tahun) sebesar 2\%, usia remaja akhir (17-25 tahun) sebesar 5\%, usia dewasa awal (26-35 tahun) sebesar 3\%, usia dewasa akhir (36-45 tahun) sebesar 7\%, usia lansia awal (46-55 tahun) sebesar 6\%, usia lansia akhir (56-65 tahun) sebesar 6\%, dan usia manula ( $>65$ tahun) sebesar $10 \%$. Kejadian pneumonia terbanyak diderita oleh usia balita (0-5 tahun) disebabkan oleh imunitas yang belum terbentuk sempurna, saluran pernapasan yang cukup sempit, serta tingginya prevalensi kolonisasi bakteri patogen di nasofaring (Price SA, 2006). Selain itu, pada anak-anak dengan keadaan kurang gizi berpeluang sebesar 6,25 kali menderita pneumonia dibandingkan dengan anak-anak yang memiliki status gizi yang baik (Hartati, 2011). Sedangkan pada usia lanjut (geriatri) angka kejadian pneumonia yang terjadi 5 sampai 10 kali lebih besar dibandingkan usia dewasa. Pada usia ini terjadi banyak perubahan akibat proses penuaan dan faktor komorbid (Kuluri, 2015). Fungsi sistem imunitas tubuh (immunocompetence) menurun sesuai umur. Kemampuan imunitas tubuh melawan infeksi menurun termasuk kecepatan respons imun dengan peningkatan usia.Salah satu komponen utama sistem kekebalan tubuh adalah sel $\mathrm{T}$, suatu bentuk sel darah putih (limfosit) yang berfungsi mencari jenis penyakit pathogen lalu merusaknya. Limfosit dihasilkan oleh kelenjar limfe yang penting bagi tubuh untuk menghasilkan antibodi melawan infeksi. Secara umum, limfosit tidak berubah banyak pada usia tua, tetapi konfigurasi limfosit dan reaksinya melawan infeksi berkurang (Fatmah, 2006).

\section{Pengobatan Pneumonia}

\section{a. Golongan dan Jenis Antibiotik}

Tabel 1 Profil Penggunaan Antibiotik Pasien Pneumonia di Instalasi Rawat Inap RSUD A. W. Sjahranie Samarinda Periode Tahun 2015

\begin{tabular}{cccc}
\hline Golongan & Jenis & Jumlah & Persentase (\%) \\
\hline Penisilin & Ampisilin & 23 & 16,16 \\
Kuinolon & Amoksisilin & 4 & \\
& Siprofloksasin & 11 & 8,38 \\
& Levofloksasin & 2 & \\
Makrolida & Moksifloksasin & 1 & 2,4 \\
& Eritromisin & 3 & \\
Sefalosporin & Azitromisin & 1 & 47,30 \\
& Sefiksim & 12 & \\
& Seftriakson & 36 & 1,8 \\
Kombinasi & Sefotaksim & 29 & 1,2 \\
& Sefpirom & 2 & 0,6 \\
Nitroimidazole & Sefobaktam & 1 & 0,6 \\
Derivat Azol & Kotrimoksazol & 2 & 1,8 \\
Poliens & Metronidazol & 2 & 0,6 \\
Karbapenem & Flukonazol & 1 & 19,16 \\
Antibiotik Lainnya & Nistatin & 1 & \\
Aminoglikosida & Meropenem & 3 & 1 \\
\hline
\end{tabular}


Dari tabel tersebut diperoleh profil pengobatan dalam penggunaan antibiotik berupa golongan dan jenis obat yang digunakan dalam pengobatan pasien pneumonia di instalasi rawat inap RSUD A. W. Sjahranie Samarinda periode tahun 2015 di antaranya terdapat golongan antibiotik penisilin, aminoglikosida, kuinolon, makrolida, sefalosporin generasi ketiga, sefalosporin generasi keempat, kombinasi, antibiotik lain, beta laktam lain, dan antifungi. Dari tabel tersebut, penggunaan antibiotik yang paling banyak digunakan ialah golongan sefalosporin generasi ketiga sebesar 46,10\% dengan jenis antibiotik seftriakson. Sefalosporin bekerja dengan menghambat sintesis dinding sel mikroba, dimana yang dihambat ialah reaksi transpeptidase tahap ketiga dalam rangkaian reaksi pembentukan dinding sel. Sefalosporin aktif terhadap mikroba gram positif maupun gram negatif dengan spektrum antimikroba masing-masing derivat bervariasi (Tanu, 2012). seftriakson diberikan pada pasien pneumonia karena merupakan antibiotik yang memiliki spektrum luas alasannya karena belum diketahui penyebab terjadinya pneumonia (Kuluri, 2015).

\section{b. Rute Pemberian Obat Antibiotik}

Tabel 2 Profil Rute Pemberian Antibiotik Pasien Pneumonia di Instalasi Rawat Inap RSUD A. W. Sjahranie Samarinda Periode Tahun 2015

\begin{tabular}{ccc}
\hline Jenis Rute & Jumlah & Persentase (\%) \\
\hline Intravena & 150 & 88,76 \\
Peroral & 19 & 11,24 \\
\hline
\end{tabular}

Dari tabel di atas diperoleh bahwa rute pemberian antibiotik pada pasien pneumonia dilakukan melalui rute intravena dan rute peroral. Pemberian antibiotik secara intravena adalah rute yang paling banyak dilakukan dengan persentase sebesar $88,76 \%$. pemberian bentuk sediaan injeksi intravena dilihat dari kondisi pasien pada saat masuk rumah sakit yang biasanya menunjukkan adanya gejala sesak napas. Dengan pemberian intravena diharapkan efek terapi dapat diperoleh lebih cepat. WHO menyarankan pengobatan pneumonia sebaiknya dirawat secara poliklinis dengan antibiotik oral, tetapi ketika didiagnosis dengan pneumonia berat, maka pasien dirawat-inapkan dan diberikan antibiotik secara parenteral (Kuluri, 2015). Penggantian terapi intravena menjadi oral dipertimbangkan jika ada perbaikan yang jelas, terutama setelah 24 jam terapi dengan intravena pada saat temperatur turun dan gejala kesulitan bernapas membaik (Suharjono, 2009).

\section{c. Frekuensi Pemberian Obat Antibiotik}

Berdasarkan data pada tabel 3, frekuensi pemberian antibiotik pada pasien pneumonia didasarkan atas aksi bakterisidal antimikroba, yakni aksi berdasarkan time dependent dan concentration dependent. Pada tabel, frekuensi pemberian obat bervariasi tiap golongan antibiotik, namun interval pemberian 4 kali dalam sehari jarang diberikan. Diketahui bahwa proporsi interval dosis bervariasi tergantung spesien patogen yang terlibat, seperti staphylococci memerlukan waktu yang pendek sedangkan untuk menghambat streptococci dan bakteri gram negatif diperlukan waktu yang panjang. Sehingga pada frekuensi pemberian beta laktam dan sefalosporin adalah 2-3 kali tergantung spesien bakteri target. 
Tabel 3 Profil Frekuensi Pemberian Antibiotik Pasien Pneumonia di Instalasi Rawat Inap RSUD A. W. Sjahranie Samarinda Periode Tahun 2015

\begin{tabular}{|c|c|c|c|c|c|}
\hline \multirow{2}{*}{ Golongan } & \multirow{2}{*}{ Jenis } & \multicolumn{4}{|c|}{ Frekuensi } \\
\hline & & 1x1 & $2 \times 1$ & $3 \times 1$ & $4 \times 1$ \\
\hline \multirow[t]{2}{*}{ Penisilin } & Ampisilin & & $\sqrt{ }$ & $\sqrt{ }$ & $\sqrt{ }$ \\
\hline & Amoksisilin & & & $\sqrt{ }$ & \\
\hline \multirow[t]{3}{*}{ Kuinolon } & Siprofloksasin & & $\sqrt{ }$ & & \\
\hline & Levofloksasin & $\sqrt{ }$ & & & \\
\hline & Moksifloksasin & $\sqrt{ }$ & & & \\
\hline \multirow[t]{2}{*}{ Makrolida } & Eritromisin & & & $\sqrt{ }$ & $\sqrt{ }$ \\
\hline & Azitromisin & $\sqrt{ }$ & & & \\
\hline \multirow[t]{4}{*}{ Sefalosporin } & Sefiksim & & $\sqrt{ }$ & $\sqrt{ }$ & \\
\hline & Seftriakson & & $\sqrt{ }$ & & \\
\hline & Sefotaksim & & $\sqrt{ }$ & $\sqrt{ }$ & \\
\hline & Sefpirom & & $\sqrt{ }$ & $\sqrt{ }$ & \\
\hline \multirow[t]{2}{*}{ Kombinasi } & Sefobaktam & & $\sqrt{ }$ & & \\
\hline & Kotrimoksazol & & $\sqrt{ }$ & & \\
\hline Nitroimidazole & Metronidazol & & & $\sqrt{ }$ & \\
\hline Derivat Azol & Flukonazol & $\sqrt{ }$ & & & \\
\hline Poliens & Nistatin & & & $\sqrt{ }$ & \\
\hline Karbapenem & Meropenem & & & $\sqrt{ }$ & \\
\hline Antibiotik Lain & Kloramfenikol & & & $\sqrt{ }$ & \\
\hline Aminoglikosida & Gentamisin & $\sqrt{ }$ & $\sqrt{ }$ & & \\
\hline
\end{tabular}

\section{d. Pengobatan Suportif Pneumonia}

Berdasarkan data tabel 4, selain memperoleh terapi antibiotik, pasien pneumonia juga mendapatkan terapi suportif yang bertujuan mendukung keberhasilan terapi dari terapi antibiotik dengan mengurangi gejala pneumonia yang memperburuk kondisi pasien. Adapun terapi suportif yang diberikan di antaranya antihistamin bekerja menekan gejala-gejala alergi dengan persentase penggunaan $9 \%$, antiinflamasi bekerja mengurangi peradangan yang ditimbulkan dengan persentase sebesar 19\%, bronkodilator bekerja dengan memperluas saluran udara dan mempermudah untuk bernafas dengan persentase sebesar $33,11 \%$, antipiretik berperan meredakan gejala panas pasien dengan persentase penggunaan 17,68\%, analgesik berperan menghilangkan rasa nyeri tanpa harus menghilangkan kesadaran seseorang sebesar 0,32\%, dekongestan berperan menyusutkan selaput hidung yang membengkak dan membuatnya lebih mudah untuk bernapas sebesar $0,32 \%$, antitusif bekerja 
menghentikan batuk secara langsung dengan menekan refleks batuk pada sistem saraf pusat di otak persentase penggunaannya sebesar $2,25 \%$. dan mukolitik-ekspektoran berperan tidak menekan refleks batuk, melainkan bekerja dengan mengencerkan dahak sehingga lebih mudah dikeluarkan dengan persentase penggunaan $18,33 \%$.

Tabel 4 Profil Terapi Suportif Pasien Pneumonia di Instalasi Rawat Inap RSUD A. W. Sjahranie Samarinda Periode Tahun 2015

\begin{tabular}{|c|c|c|c|}
\hline Golongan & Jenis & Jumlah & Total dan Persentase \\
\hline \multirow[t]{4}{*}{ Antihistamin } & Loratadin & 1 & $28(9 \%)$ \\
\hline & Desonid & 1 & \\
\hline & Setirizin & 2 & \\
\hline & CTM & 24 & \\
\hline Dekongestan & Pseudoefedrin $\mathrm{HCl}$ & 1 & $1(0,32 \%)$ \\
\hline \multirow[t]{4}{*}{ Antiinflamasi } & Ibuprofen & 1 & $59(19 \%)$ \\
\hline & Deksametason & 51 & \\
\hline & Metilprednisolon & 5 & \\
\hline & Ketorolac & 2 & \\
\hline \multirow{4}{*}{$\begin{array}{l}\text { Mukolitik Dan } \\
\text { Ekspektoran }\end{array}$} & Ambroksol & 48 & $57(18,32 \%)$ \\
\hline & Asetil sistein & 2 & \\
\hline & Erdostein & 3 & \\
\hline & Bromheksin & 4 & \\
\hline Antitusif & Codein & 7 & $7(2,25 \%)$ \\
\hline \multirow[t]{6}{*}{ Bronkodilator } & Combivent $\AA$ & 12 & $103(33,11 \%)$ \\
\hline & Ventolin ${ }^{\circledR}$ & 34 & \\
\hline & Salbutamol & 31 & \\
\hline & Aminofilin & 7 & \\
\hline & Terbutalin Sulfat & 1 & \\
\hline & Efedrin & 18 & \\
\hline Analgesik & Tramadol & 1 & $1(0,32 \%)$ \\
\hline Antipiretik & PCT & 55 & $55(17,68 \%)$ \\
\hline
\end{tabular}

\section{e. Terapi Penyakit Penyerta}

Berdasarkan tabel 5, terdapat banyak obat yang diberikan pada pasien pneumonia yang memiliki diagnosa dengan penyakit penyerta. Obat yang digunakan untuk mengatasi penyakit penyerta paling banyak digunakan ialah antasid dan ulkus untuk menetralisir atau mengurangi produksi asam lambung sebesar 31,35\%. Diketahui bahwa efek samping dari penggunaan antibiotik sebagian besar menimbulkan gangguan gastrointestinal berupa mual dan muntah. 
Tabel 5 Profil Terapi Penyakit Penyerta Pasien Pneumonia di Instalasi Rawat Inap RSUD A. W. Sjahranie Samarinda Periode Tahun 2015

\begin{tabular}{|c|c|c|c|}
\hline Golongan & Jenis & Jumlah & Total Dan Persentase \\
\hline \multirow[t]{7}{*}{ Vitamin } & Cernevit@ & 1 & $10(8,47 \%)$ \\
\hline & Kalmeco® & 1 & \\
\hline & Likurmin $®$ & 1 & \\
\hline & Neurobion 5000® & 1 & \\
\hline & Neurosanbe® & 2 & \\
\hline & Vitamin K & 2 & \\
\hline & Neurodex® & 2 & \\
\hline Vasodilator & Sitikolin & 2 & $2(1,70 \%)$ \\
\hline Nootropik & Pirasetam & 2 & $2(1,70 \%)$ \\
\hline \multirow[t]{6}{*}{ Antasid Dan Ulkus } & sukralfat & 5 & $37(31,35 \%)$ \\
\hline & Ranitidin & 19 & \\
\hline & Omeprazol & 7 & \\
\hline & Esomeprazol & 2 & \\
\hline & Pantoprazol & 3 & \\
\hline & Acitral & 1 & \\
\hline \multirow[t]{3}{*}{ Antiemetik } & Metoklopramid & 1 & $9(7,62 \%)$ \\
\hline & Ondansetron & 6 & \\
\hline & Domperidon & 2 & \\
\hline Laksatif & Laxadine & 3 & $3(2,54 \%)$ \\
\hline \multirow[t]{2}{*}{ Antiplatelet } & Aspilet ${ }^{\circledR}$ & 2 & $4(3,39 \%)$ \\
\hline & Clopidogrel & 2 & \\
\hline \multirow[t]{3}{*}{ Antidiare } & Oralit & 1 & $5(4,23 \%)$ \\
\hline & Attalpulgite & 1 & \\
\hline & Zink & 3 & \\
\hline \multirow[t]{3}{*}{ Antidiabetik } & Levemir $®$ & 2 & $7(6 \%)$ \\
\hline & Apidra® & 4 & \\
\hline & Novorapid® & 1 & \\
\hline \multirow[t]{2}{*}{ Antiepilepsi } & Fenitoin & 4 & $5(4,23 \%)$ \\
\hline & Asam Valproat & 1 & \\
\hline \multirow[t]{5}{*}{ antihipertensi } & Amlodipin & 4 & $14(11,86 \%)$ \\
\hline & Telmisartan & 3 & \\
\hline & Captopril & 1 & \\
\hline & Bisoprolol & 1 & \\
\hline & Furosemid & 5 & \\
\hline \multirow[t]{2}{*}{ Antikonvulsan } & Fenobarbital & 2 & $6(5,08 \%)$ \\
\hline & Diazepam & 4 & \\
\hline Antifibrinolitik & As. Traneksamat & 5 & $5(4,23 \%)$ \\
\hline Antidepresan & Alprazolam & 2 & $2(1,70 \%)$ \\
\hline Antitiroid & Levotiroksin & 1 & $1(0,84 \%)$ \\
\hline Antimigrain & Flunarizin & 1 & $1(0,84 \%)$ \\
\hline \multirow[t]{2}{*}{ Inotropik } & Dopamin & 1 & $2(1,70 \%)$ \\
\hline & Dobutamin & 1 & \\
\hline Antigout & Allupurinol & 1 & $1(0,84 \%)$ \\
\hline Antiangina & Fasorbid & 1 & $1(0,84 \%)$ \\
\hline Anti Hemarhoid & Ardium $\AA$ & 1 & $1(0,84 \%)$ \\
\hline
\end{tabular}




\section{Potensi Interaksi Pengobatan Pneumonia}

Tabel 6 Potensi Interaksi Pengobatan Pneumonia di Instalasi Rawat Inap RSUD A. W. Sjahranie Samarinda Periode Tahun 2015

\begin{tabular}{cccc}
\hline Jenis Obat (I) & Jenis Obat (II) & $\begin{array}{c}\text { Derajat } \\
\text { Keparahan }\end{array}$ & $\begin{array}{c}\text { Jenis Interaksi } \\
\text { Obat }\end{array}$ \\
\hline Gentamisin & Furosemid & Mayor & Farmakodinamik \\
Dexametason & Furosemid & Moderat & Farmakodinamik \\
Dexametason & Ibuprofen & Moderat & Farmakodinamik \\
Ampisilin & Kloramfenkol & Moderat & Farmakodinamik \\
Aminofilin & Albuterol & Moderat & Farmakodinamik \\
Albuterol & Furosemid & Moderat & Farmakodinamik \\
Gentamisin & Sefotaksim & Moderat & Farmakodinamik \\
Gentamisin & Seftriakson & Moderat & Farmakodinamik \\
Gentamisin & Sefiksim & Moderat & Farmakodinamik \\
Gentamisin & Ibuprofen & Moderat & Farmakodinamik \\
Siprofloksasin & Albuterol & Moderat & Farmakodinamik \\
Siprofloksasin & Insulin Apidra & Moderat & Farmakodinamik \\
Siprofloksasin & Insulin Levemir & Moderat & Farmakodinamik \\
Siprofloksasin & Ondansetron & Moderat & Farmakodinamik \\
Siprofloksasin & Omeprazol & Moderat & Farmakodinamik \\
Sefiksim & Gentamisin & Moderat & Farmakodinamik \\
Seftriakson & Furosemid & Moderat & Farmakodinamik \\
Sefotaksim & Furosemid & Moderat & Farmakodinamik \\
Albuterol & Insulin Levemir & Moderat & Farmakodinamik \\
Albuterol & Insulin Novorapid & Moderat & Farmakodinamik \\
Siprofloksasin & Sukralfat & Moderat & Farmakokinetik \\
\hline
\end{tabular}

Berdasarkan tabel di atas, terdapat beberapa interaksi antar obat dalam pengobatan pasien pneumonia. Sebagian besar jenis interaksi yang terjadi ialah interaksi farmakodinamik dengan tingkat keparahan paling banyak adalah moderat. Adapun interaksi farmakodinamik dengan derajat keparahan moderat terjadi pada interaksi gentamisin dengan furosemid, dimana interaksi ini dapat meningkatkan resiko terjadinya nefrotoksik. Interaksi obat berupa interaksi farmakokinetik terdapat pada penggunaan bersama antara siprofloksasin dengan sukralfat dengan derajat keparahan moderat, dimana sukralfat bertugas menurunkan absorpsi gastrointestinal dari siprofloksasin.

\section{KESIMPULAN}

Karakteristik pasien pneumonia yang meliputi jenis kelamin yang paling banyak menderita pneumonia adalah laki-laki sebanyak 51 pasien $(52,58 \%)$, sedangkan pasien pneumonia yang paling banyak menderita pneumonia adalah pada usia 0-5 tahun sebanyak 56 pasien $(57,73 \%)$. Pengobatan berdasarkan pemilihan golongan dan jenis obat yang paling sering digunakan pada penggunan antibiotik golongan dan jenis obat yang paling banyak digunakan adalah golongan sefalosporin $47,30 \%$ yakni jenis antibiotik seftriakson. Rute pemberian obat antibiotik yang paling banyak diberikan ialah secara intravena sebesar $88,76 \%$. Frekuensi pemberian obat antibiotik yang diberikan bervariasi tergantung pada spesien bakteri target. Terapi suportif yang banyak digunakan ialah golongan bronkodilator 
$(33,11 \%)$. Interaksi obat yang terjadi berupa interaksi farmakodinamik dan interaksi farmakokinetik.

\section{DAFTAR PUSTAKA}

Abbas Merdjani. 2002. Demam Chikungunya. Dalam Sumarmo S. Soedarmo, Henry Garna, Sri Rezeki : Buku Ajar Ilmu Kesehatan Anak - Infeksi dan Penyakit Tropis. Edisi I. Bagian Ilmu Kesehatan Anak FKUI. h. 260, 266: Jakarta

Depkes RI. 2013. Riset Kesehatan Dasar. Jakarta: Kementerian Kesehatan RI.

Fatmah. 2006. Respon Imunitas Yang Rendah Pada Tubuh Manusia Usia Lanjut. MAKARA, Kesehatan, Vol. 10, No. 1

Hartati, Susi. 2011. Analisis Faktor Resiko Yang Berhubungan Dengan Kejadian Pneumonia Anak Balita Di RSUD Pasar Rebo Jakarta. Jakarta: UI Press.

Hirokawa, Katsuiku, Masanori Utsuyama, Yoshio Hayashi, Masanobu Kitagawa, Takashi Makinodan And Tamas Fulop. 2013. Slower Immune System Aging In Women Versus Men In The Japanese Population. Biomed Central, 10:19.

Jawetz, E., Melnick J., Adelberg's. 2008. Medical Microbiology. Jakarta: Penerbit Buku Kedokteran EGC.

Kuluri, Lisa C. N. 2015. Evaluasi Kerasionalan Penggunaan Antibiotik Pada Pasien Lansia Dengan Pneumonia Di Instalasi Rawat Inap RSUP Prof. Dr. R. D. Kandou Manado Periode Juni 2013-Juli 2014. Jurnal Ilmiah Farmasi UNSRAT Vol. 4 No. 3.

Suharjono, Yuniati T., Sumarno, Semedi S.J. 2009. Studi Penggunaan Antibiotika Pada Penderita Rawat Inap Pneumonia (Penelitian Di Sub Departemen Anak Rumkital Dr. Ramelan Surabaya). Majalah Ilmu Kefarmasian, Vol. VI No. 3.

Tanu, Ian. 2012. Farmakologi Dan Terapi, Edisi Kelima. Jakarta: Badan Penerbit FKUI. 